\title{
Effect of experimentally induced diabetes mellitus on serum leptin level and the role of insulin replacement therapy
}

\author{
Nabil A. Soliman \\ Department of Zoology, Faculty of science, Zagazig University.
}

\begin{abstract}
The regulation of circulating leptin concentration is multifactorial and still understood. Therefore, the present study was designed: (1) to demonstrate the effect of gender on leptin concentration in intact control rats, (2) to evaluate the relationship between serum leptin concentration, serum insulin level and body weight in control rats and streptozotocin (STZ) diabetic rats (untreated and treated with insulin). A total number of 48 healthy adult albino rats of both sexes (24males\& 24 females) were used in this study. The animals were divided equally into four groups, each group was subdivided equally into -male and female subgroups. Group $1\left(\mathrm{G}_{1}\right)$ : served as control group, group $2\left(\mathrm{G}_{2}\right)$ : experimental diabetics group (not treated) and group $3\left(\mathrm{G}_{3}\right)$ \& group $4\left(\mathrm{G}_{4}\right)$ : experimental diabetic group treated with insulin for 2 and 21 days. These groups were examined for the following parameters: body weight, blood glucose level, serum insulin and leptin concentration. It was found that serum leptin level was significantly higher in female than in male control group. However, this difference could not be detected in between male and female rats in all other studied groups. Moreover, a strong positive correlation was found between leptin concentration and insulin hormone level, and body weight in control male and female rats. STZ-induced diabetes associated with a significant rapid decrease in circulating leptin concentration $\left(G_{2}\right)$, this decrease was accompanied with a significant decrease in both serum insulin level and body weight, then, it was rapidly reversed by insulin treatment for 2 days $\left(\mathrm{G}_{3}\right)$ and 21 days $(\mathrm{G} 4)$. There was also a positive correlation between serum leptin concentration, body weight and serum insulin level in this diabetic group. However, leptin was found to change in an inverse proportion to the variation in blood glucose concentration in both male and female diabetic groups. The direct relationship of serum leptin concentration to serum insulin concentration and the inverse relationship of leptin concentration to blood glucose level were preserved in both male and female insulin replacement therapy groups.

In conclusion, in adult albino rats, several factors are involved in the regulation of circulating leptin level such as gender, body weight, blood glucose level and serum insulin concentration.
\end{abstract}

\section{Introduction}

The discovery of the obese gene in the mouse and its conserved homologue in humans has led many researchers to work hardly to find out the factors which could regulate the expression of leptin gene and in turn could regulate metabolism and behavior ( Saladine et al., 1996). Leptin was first described as an adiposity derived signaling factor, which, after interaction with specific receptors, induces a peleiotropic respo nse including control of body weight and energy expenditure. Although research has moved ahead rapidly there 
are still more questions about the regulatory pathways that control leptin and modulate leptin expression (Auwerx and Stales, 1998).

Several lines of evidence suggested that the hypothalamus is a critical target for the satiety effect of leptin. This effect may be mediated partly by inhibition of neuropeptide Y (NPY) which is a potent stimulator of food intake (Erickson et al., 1996). Other candidates of which activity could be modulated by leptin and which are active in the brain are melanocyte stimulating hormone (Huszer et al., 1997), glucagon-like peptide , cortico tropin releasing hormone or related factor urocortin), and melanin concent rating hormone.(Spina et al., 1996).

A remarkable gender difference in serum leptin levels in both human and animal studies were reported. It was found that intact female rats had a higher serum leptin level than intact male rats(Yacout et al., 2000). Moreover, profound gender differences in circulating leptin was documented in adult humans (Havel et al., 1996), children (Lahlou et al., 1997), and healthy subjects and young patients with insulin dependant diabetes mellitus (IDDM)(Verroti et al., 1998).

Previous studies reported that the amount of leptin mRNA in adipocytes correlates with body weight (Hamilton et al., 1995). It was found that circul ating leptin concentration is elevated in the obese state; decrease following weight loss and increase again with weight (Nicklas et al., 1997) Moreover, it was reported by Considine et al. (1996) that a reduction of $10 \%$ in body weight is associated with $53 \%$ reduction in serum leptin. Even a $4 \%$ reduction in body weight over a period of 7 days resulted in $61 \%$ decrease in leptin values in both sexes (Dubuc et al., 1998). In addition, Caro et al. (1996) reported that a small (10\%) increase in body weight results in a $300 \%$ increase in serum leptin.

A strong positive correlation was reported between serum leptin concent ration and body fat content and serum insulin level (McGreoger et al., 1996). In addition, some but not all invest igators found that insulin is a potent regulator of plasma leptin level regard less of their relation-ship with body weight and total body fat (Ahren et al., 1997 and Kiess et al., 1998). However, other investigators suggested that insulin does not stimulate leptin production (Dagog-Jack et al., 1996). Regulation of (ob) gene expression by insulin is also supported by findings that (ob) gene expression is reduced in insulin dependent diabetes which is accompanied by hypoinsulinemia (Sivitz et al., 1996 and Sivitz et al., 1998). However, Tuominen et al. (1997) demonstrated that leptin levels were higher in insulin dependent diabetes mellitus. In addition, Verroti et al.(1998) showed that type I diabetes does not modify serum leptin concentration.

Some studies showed that insulin therapy resulted in normalization of lower leptin levels in diabetic animals (Mac Dougard et al., 1998), while others did not (Backer et al., 1995).

Because of the variability of information mentioned and the contradiction of reports about some of the factors that could regulate the serum leptin levels, this study was designed to:

1. Demonstrate the effect of gender on leptin concentration in the intact control group and evaluate the effect of gender under the influence of some metabolic disorders as experimentally-induced diabetes mellitus (untreated and treated with insulin).

2. Evaluate the relationship between leptin concentration, serum insulin level and body weight in control 
intact rats, experimentally diabetic rats (untreated and treated with insulin).

3. Study the effect of experimental diabetes and Insulin replacement therapy for 2 days and for 15 days on serum leptin concen-tration.

\section{Material \& Methods}

Experimental Animals:

A total number of 48 healthy adult albino rats of both sexes ( 24 adult males \& 24 adult females) weighting 215- 318 gms were used for this study. The animals were kept in steel wire cages at the animal house throughout the study, and fed the same type of food to avoid the effect of different food elements on the experiments, the diet consisted of mixed commercial rat laboratory chow. They had free access to water and kept at room temperature. The animals were divided equally into four groups:

$\mathrm{G}_{1}$ : This group consisted of 6 male and 6 female rats and served as a control group.

$\mathrm{G}_{2}$ : This group consisted of 6 male and 6 female rats in which diabetes was experimental induced by intravenous injection of freshly prepared solution of streptozotocin (STZ) (Sigma, $65 \mathrm{mg} / \mathrm{kg}$, dissolved in $0.2 \mathrm{mmol} / \mathrm{l}$ sodium citrate, pH 4.5) (Lutz and Pardridge, 1993). For 48 hours after treatment with STZ, the water supply was supple-mented with $5 \%$ glucose to minimize deaths from acute hypoglycemia (Harry et al., 1993). Within 48 to 72 hours after injection, the criteria of diabetes such as weight loss, glycosuria and hyperglycemia were observed in these rats.

$\mathrm{G}_{3}$ and $\mathrm{G}_{4}$ consisted of 12 male and 12 female diabetic rats for each group in which diabetes was induced as previously mentioned in $G_{2}$. Diabetic rats were treated with regular insulin
(R) (Eli lilly company, Indianpolis, IN) and NPH $(\mathrm{N})$ insulin (Nordisk Gentofte A/S Laboratorium, Denmark.) (2 U R at diagnosis of diabetes and then $1 \mathrm{R} / 3 \mathrm{~N}$ at $6 \mathrm{PM}$ and $1 \mathrm{R} / 1 \mathrm{~N}$ at $9 \mathrm{AM}$ daily) subcutaneously for 2days after induc tion of diabetes (Sivitz et al., 1998), in $\mathrm{G}_{3}$, and for 21 days in $\mathrm{G}_{4}$.

The initial and final body weights were recorded for rats in all groups (before and after induction of diabetes).

\section{Sampling Of Blood:}

Blood samples were obtained by decapitation of rats after lightly anesth etized with pentobarbital $(90 \mathrm{mg} / \mathrm{kg})$ betw een 9-11 A.M to avoid the circadian rhythm in serum leptin. Blood glucose was determined in all groups using Reflolux reflectance photometers Boehringer Mannheim UK (Diagnostic \&Biochemicals) Ltd. Bell Lanen, Lewes, East Sussex, BN7 1LG GB. The serum was separated by allowing the blood to clot then centrifuged at 3000 rpm for 10 minutes and stored deep frozen at $-20^{\circ} \mathrm{C}$ until used for: 1estimation of serum insulin level in all groups by using (MEDGENIX-INSEASIA-Enzyme Amplified Sensitivity Immunoassay) Kits: For the measure ement of Insulin in serum by Immunoe nzymetric Assay. BioSource Europe S.A. 2- Determination of serum leptin levels in all groups by using active leptin ELISA kit (DSL-10-23100 Diagnostic Systems Laborato-ries, Inc. Corporate Headquarters, 445 Medical center Blvd. Webster, Texas, USA).

Statistical analysis:

All data were expressed as mean \pm SE and statistically analyzed according to Yamane (1970). A P value $<0,05$ was considered significant.

\section{RESULTS}

Table (1) Fig. (1) illustrate the effect of gender on serum leptin level in 
control, diabetic and insulin treated diabetic male and female rats. It was found that the mean value of leptin serum concentration in the control female group $(1.80 \pm 0.052 \mathrm{ng} / \mathrm{ml}$, $\mathrm{P}<0.001)$ was statistically higher than in the control male group $(1.25 \pm 0.05$ $\mathrm{ng} / \mathrm{ml})$. However, this difference could not be detected in between male and female in all other studied groups $[(0.46 \pm 0.042 ; 0.56 \pm 0.066 \mathrm{ng} / \mathrm{ml}), \mathrm{P}>0.05$, respectively for diabetic group), $(1.02 \pm 0.05 ; \quad 1.1 \pm 0.07 \mathrm{ng} / \mathrm{ml}, \quad \mathrm{P}>0.05$, respectively, for 2 days insuline replacement) and $(1.52 \pm 0.12 ; 1.6 \pm 0.1$ $\mathrm{ng} / \mathrm{ml}, \mathrm{P}>0.05$ respectively, for 21 days insulin replacement)].

Table $(2,3)$ show serum leptin concentration, insulin level, blood glucose level and body weight in diabetic (untreated) and diabetic treated with insulin replacement for 2 and 21 days in male and female rats compared with the control group. It was found that the mean leptin concentration in both male and female diabetic rats $[(0.46 \pm 0.042 ; 0.56 \pm 0.066 \mathrm{ng} / \mathrm{ml}$, respe ctively) was significantly lower than in the male and female control groups $[(1.25 \pm 0.05 ; 1.80 \pm 0.052 \mathrm{ng} / \mathrm{ml}$, respect ively)] (Fig.1).

It was observed that the decrease in serum leptin concentration in diabetic male and female rats was significantly corrected with insulin replacement therapy for 2 and 21 days to reach a mean value $[(1.02 \pm 0.052 ; \quad 1.1 \pm 0.07 \mathrm{ng} / \mathrm{ml}, \quad$ and $(1.52 \pm 0.12 ; 1.6 \pm 0.1 \mathrm{ng} / \mathrm{ml}$, respectively, $\mathrm{P}<0.001$ ), nearer to that of normal control rats specially with 21 days insulin replacement. As regards, the changes in serum insulin level, there was no significant difference between male and female control groups, indicating that, insulin may not be responsible for the gender difference in serum leptin concentration observed in Table (1).
However, it was noted that the mean value of isulin level in both male and female diabetic groups was lower than that of control male and female groups $[(1.5 \pm 0.56 ; 1.36 \pm 0.4 \mu \mathrm{IU} / \mathrm{ml})$ respect ively, for diabetic groups) and $[(30.4 \pm 1.4 ; 31.3 \pm 2.56 \mu \mathrm{IU} / \mathrm{ml}$, respect ively, for control groups].

Insulin replacement therapy for 2 days and 21 days was found to cause statistically significant increase in serum insulin concen-tration in both male and female rats $[(51.4+4.8$; $56.4 \pm 5.8 \mu \mathrm{IU} / \mathrm{ml}$, respectively, for 2 days group, $\mathrm{P}<0.001)$ and $(97.4 \pm 6.4$; $86.3 \pm 7.4 \mu \mathrm{IU} / \mathrm{ml}$, respectively, for 21 days group)] when compared to either control or diabetic groups (Fig. 2).

Regarding the changes in blood glucose level, it was found that, there was a statistically significant increase in blood glucose level in diabetic male and female groups $[(342.7 \pm 34.5 ; 338.5 \pm 21.6$ $\mathrm{mg} / \mathrm{dl}$, respectively)], when compared with the control groups $[(89.5 \pm 4.2$; $92.8 \pm 4.9 \mathrm{mg} / \mathrm{dl}$, respectively)].

Insulin replacement therapy for 2 and 21 days was associated with a highly significant decrease in blood glucose level in male and female rats $[(70.2 \pm 5.04,72.0 \pm 4.4 \mathrm{mg} / \mathrm{dl}$, respecti vely, for 2 days group) and (60.5 \pm 2.3 , $66.8 \pm 2.8 \mathrm{mg} / \mathrm{dl}$, respectively, for 21 days group)], when compared with diabetic groups (Fig. 3).

It was also found that, the body weight was significantly decreased in diabetic male and female rats $(271.8 \pm 6.3$, $214.7 \pm 7.4 \mathrm{gms}$, respectively). Treatment of diabetic male and female rats with insulin for 2 and 21 days resulted in a significant correction of the reduction in body weight in both male and female rats compared to diabetic groups $[(295.7 \pm 5.3 ; 235 \pm 2.88 \mathrm{gms}$, respect ively, for 2 days group) and $(297.7 \pm 6.02 ; \quad 238.5 \pm 2.6 \mathrm{gms}$, 
respectively, for 21 days insulin replacement group)] (Fig. 4).

Leptin concentration, insulin and body weight relationship in the control male and female groups:

A strong positive correlation was observed between leptin concentration and body weight in control male and female rats groups $(r=+0.75 ;+0.73$, respectively, $\mathrm{P}<0.001)$.

Moreover, a strong positive correlation was also found between leptin concentration and insulin hormone level in control male $(r=$ $+0.76)$ and in control female $(\mathrm{r}=+0.9)$ rats groups $(\mathrm{P}<0.001)$. Hence, it is clearly apparent that serum leptin concentration change in a direct proportion to the variation in body weight and insulin hormone serum level in the control group.

Leptin concentration, body weight, insulin and blood glucose concentration relationship in diabetic (untreated) groups:

Serum leptin level showed very highly significant direct correlation with body weight $(\mathrm{r}=+0.7 ;+0.77)$ and $\mathrm{a}$ significant direct correlation with serum insulin level $(\mathrm{r}=+0.7 ;+0.71)$ in male and female groups respectively, and highly significant inverse correlation with blood glucose level in male and female groups $(\mathrm{r}=-0.75 ;-0.71$, respectively).

The positive correlation found between leptin concentration and body weight and insulin level in this study (in the diabetic group) revealed a significant rise of leptin concentration with the increase of body weight and serum insulin level. Moreover, leptin was found to be change in an inverse proportion to the variation in blood glucose concentration in both male and female diabetic groups.

Leptin concentration, insulin and blood glucose concentration relation ship in the male and female diabetic rats treated with insulin replacement therapy for 2 and 21 days:

Serum leptin level concen-tration in male groups, showed insignificant direct correlation $(\mathrm{r}=+0.41)$ with serum insulin level and insignificant correl ation with blood glucose level $(\mathrm{r}=$ 0.03 ) for 2 days insulin replacement therapy.

On the other hand, serum leptin level showed very highly significant direct correlation $(r=+0.85)$ with serum insulin level and highly significant inverse $(r=-0.66)$ with blood glucose level for 21 days of insulin replacement. While, in female groups, serum leptin level showed highly significant direct correlation $(\mathrm{r}=+0.68)$ with serum insulin level and in-significant inverse correlation with glucose level $(r=$ 0.26 ) for 2 days insulin replacement. Moreover, serum leptin level showed very highly significant direct correlation $(r=+0.75)$ with serum insulin level and highly significant inverse correlation with blood glucose $(r=-0.78)$ for 21 days insulin replacement. 
Table (1): Comparison between serum leptin concentration (ng/ml) in male and female albino rats in all studied groups.

\begin{tabular}{|c|c|c|c|c|c|c|c|c|}
\hline \multirow[t]{2}{*}{ Groups } & \multicolumn{2}{|c|}{ Control } & \multicolumn{2}{|c|}{ Diabetic group } & \multicolumn{2}{|c|}{$\begin{array}{c}\text { Diabetic treated } \\
\text { insulin } \\
\text { replacement } \\
\text { (2 days) }\end{array}$} & \multicolumn{2}{|c|}{$\begin{array}{c}\text { Diabetic treated } \\
\text { insulin } \\
\text { replacement } \\
(21 \text { days }) \\
\end{array}$} \\
\hline & Male & Female & Male & Female & Male & Female & Male & Female \\
\hline $\begin{array}{l}\begin{array}{c}\text { Leptin } \\
\text { concentration }\end{array} \\
(\mathrm{ng} / \mathrm{ml}) \mathrm{X}^{-} \pm \\
\text {S.E } \\
\text { sig. }\end{array}$ & $1.25 \pm 0.03$ & $\begin{array}{c}1.80 \pm 0.052 \\
\mathrm{P}<0.001\end{array}$ & $0.46 \pm 0.042$ & $\begin{array}{c}0.56 \pm 0.066 \\
\text { n.s. }\end{array}$ & $1.02 \pm 0.05$ & $\begin{array}{c}1.1 \pm 0.07 \\
\text { n.s. }\end{array}$ & $1.52 \pm 0.12$ & $\begin{array}{c}1.6 \pm 0.1 \\
\text { n.s. }\end{array}$ \\
\hline
\end{tabular}

$\mathrm{P}<0.001=$ Very highly significant.

n.s. $=$ not significant.

Table (2): Serum leptin concentration (ng/ml), insulin hormone level ( $\mu \mathrm{IU} / \mathrm{ml})$, blood glucose level $(\mathrm{mg} / \mathrm{dl})$ and body weight $(\mathrm{gms})$ in all studied groups of male rats.

\begin{tabular}{|c|c|c|c|c|}
\hline Parameters & $\begin{array}{c}\text { Control group } \\
\left(\mathbf{G}_{1}\right)\end{array}$ & $\begin{array}{c}\text { Diabetic } \\
\text { (untreated) } \\
\left(\mathbf{G}_{2}\right)\end{array}$ & $\begin{array}{c}\text { Insulin replacement } \\
\mathbf{2} \text { days } \\
\left(\mathbf{G}_{3}\right)\end{array}$ & $\begin{array}{c}\text { Insulin replacement 21- } \\
\text { days } \\
\left(\mathbf{G}_{4}\right)\end{array}$ \\
\hline $\begin{array}{l}\text { Leptin conc. }(\mathrm{ng} / \mathrm{ml}) \\
X^{-} \pm S . E \\
\text { Sig. }\end{array}$ & $1.25 \pm 0.05$ & $\begin{array}{c}0.46 \pm 0.042 \\
\mathrm{P}<0.001\end{array}$ & $\begin{array}{c}1.02 \pm 0.05 \\
\mathrm{P}<0.001\end{array}$ & $\begin{array}{c}1.52 \pm 0.12 \\
\mathrm{P}<0.001\end{array}$ \\
\hline $\begin{array}{l}\text { Insulin level }(\mu \mathrm{IU} / \mathrm{ml}) \\
X^{-} \pm \text {S.E } \\
\text { Sig. }\end{array}$ & $30.4 \pm 1.4$ & $\begin{array}{l}1.5 \pm 0.56 \\
P<0.001\end{array}$ & $\begin{array}{l}51.4 \pm 4.8 \\
\mathrm{P}<0.001\end{array}$ & $\begin{array}{l}97.4 \pm 6.4 \\
P<0.001\end{array}$ \\
\hline $\begin{array}{l}\text { Blood glucose }(\mathrm{mg} / \mathrm{dl}) \\
X^{-} \pm \text {S.E. } \\
\text { Fig. }\end{array}$ & $89.5 \pm 4.2$ & $\begin{array}{c}342.7 \pm 34.5 \\
<0.001\end{array}$ & $\begin{array}{c}70.2 \pm 5.04 \\
P<0.001\end{array}$ & $\begin{array}{l}60.5 \pm 2.3 \\
P<0.001\end{array}$ \\
\hline $\begin{array}{l}\text { Body weight (gms) } \\
X^{-}+\text {S.E. } \\
\text { Sig. }\end{array}$ & $305.3 \pm 3.6$ & $\begin{array}{c}271.8 \pm 6.3 \\
\mathrm{P}<0.001\end{array}$ & $\begin{array}{c}295.7 \pm 5.3 \\
P<0.01\end{array}$ & $\begin{array}{c}297.7 \pm 6.02 \\
P<0.01\end{array}$ \\
\hline
\end{tabular}

$\mathrm{P}<0.01=$ highly significant .

$\mathrm{P}<0.001=$ very highly significant. 
Table (3): Serum leptin concentration (ng/ml), insulin hormone level ( $\mu \mathrm{IU} / \mathrm{ml})$, blood glucose level $(\mathrm{mg} / \mathrm{dl})$ and body weight $(\mathrm{gms})$ in all studied groups of female rats.

\begin{tabular}{|c|c|c|c|c|}
\hline $\begin{array}{c}\text { Groups } \\
\text { Parameters }\end{array}$ & $\begin{array}{c}\text { Control group } \\
\left(\mathbf{G}_{1}\right) \\
\end{array}$ & $\begin{array}{c}\begin{array}{c}\text { Diabetic } \\
\text { (untreated) }\end{array} \\
\left(\mathbf{G}_{2}\right) \\
\end{array}$ & $\begin{array}{c}\text { Insulin } \\
\text { replacement } 2 \\
\text { days } \\
\left(\mathbf{G}_{3}\right) \\
\end{array}$ & $\begin{array}{c}\text { Insulin } \\
\text { replacement 21- } \\
\text { days } \\
\left(\mathbf{G}_{4}\right) \\
\end{array}$ \\
\hline $\begin{array}{l}\text { Leptin conc. (ng/ml) } \\
X^{-} \pm \text {S.E } \\
\text { Sig. }\end{array}$ & $1.80 \pm 0.052$ & $\begin{array}{c}0.56 \pm 0.066 \\
\mathrm{P}<0.001\end{array}$ & $\begin{array}{l}1.1 \pm 0.07 \\
\mathrm{P}<0.001\end{array}$ & $\begin{array}{l}1.6 \pm 0.1 \\
\mathrm{P}<0.001\end{array}$ \\
\hline $\begin{array}{l}\text { Insulin level }(\mu \mathrm{IU} / \mathrm{ml}) \\
X^{-} \pm \text {S.E } \\
\text { Sig. }\end{array}$ & $31.3 \pm 2.56$ & $\begin{array}{l}1.36 \pm 0.4 \\
P<0.001\end{array}$ & $\begin{array}{l}56.4 \pm 5.8 \\
P<0.001\end{array}$ & $\begin{array}{l}86.3 \pm 7.4 \\
P<0.001\end{array}$ \\
\hline $\begin{array}{l}\text { Blood glucose }(\mathrm{mg} / \mathrm{dl}) \\
\mathrm{X}^{-} \pm \text {S.E. } \\
\text { Fig. }\end{array}$ & $92.8 \pm 4.9$ & $\begin{array}{c}338.5 \pm 21.6 \\
\mathrm{P}<0.001 \\
\end{array}$ & $\begin{array}{l}72.0 \pm 4.4 \\
\mathrm{P}<0.001\end{array}$ & $\begin{array}{l}66.8 \pm 2.8 \\
\mathrm{P}<0.001 \\
\end{array}$ \\
\hline $\begin{array}{l}\text { Body weight (gms) } \\
X^{-} \pm \text {S.E. } \\
\text { Sig. }\end{array}$ & $242.7 \pm 7.5$ & $\begin{array}{c}214.7 \pm 7.4 \\
\mathrm{P}<0.05\end{array}$ & $\begin{array}{c}235.0 \pm 2.88 \\
\mathrm{P}<0.01\end{array}$ & $\begin{array}{c}238.5 \pm 2.6 \\
\mathrm{P}<0.01\end{array}$ \\
\hline
\end{tabular}

$\mathrm{P}<0.01=$ highly significant .

$\mathrm{P}<0.001=$ very highly significant .

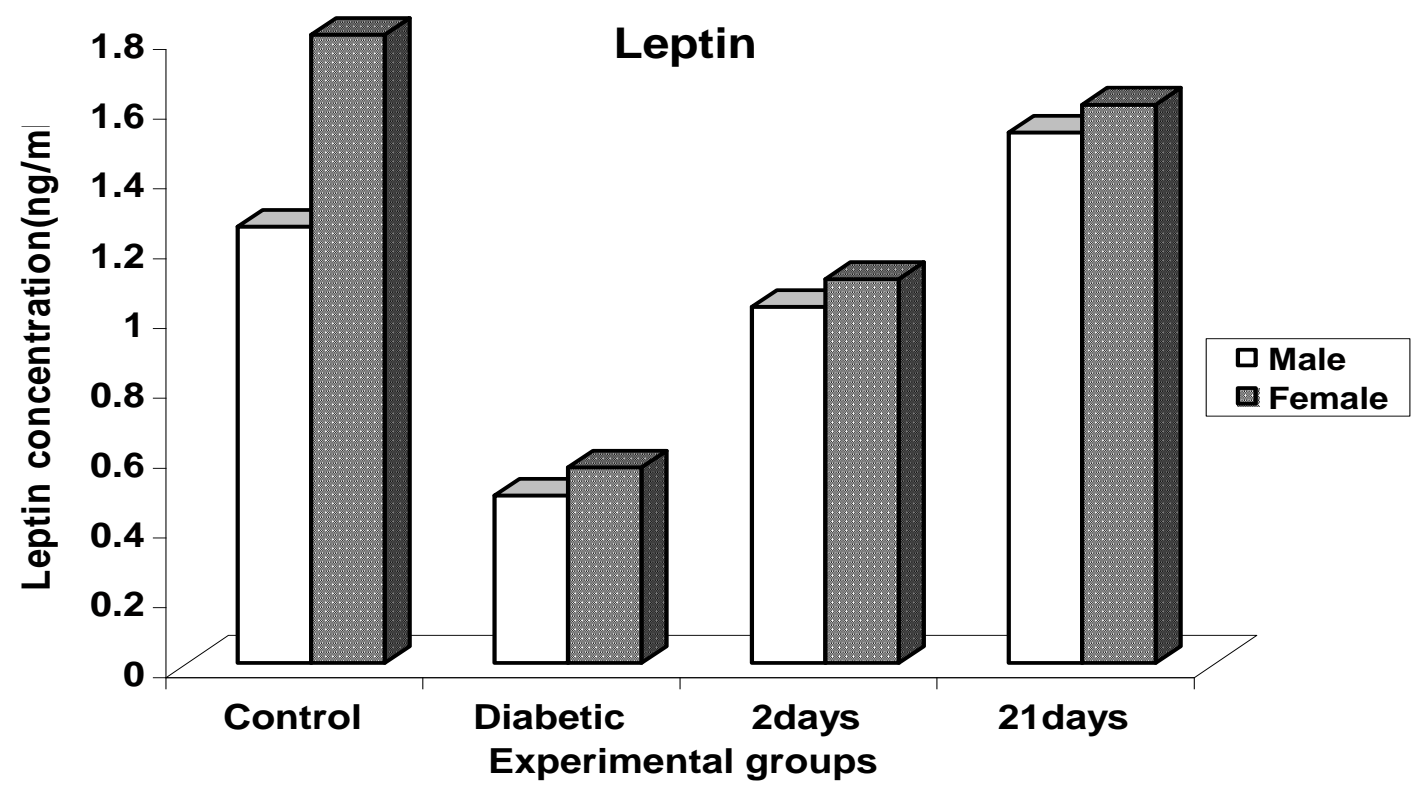

Fig. (1): Serum leptin level $(\mathrm{ng} / \mathrm{ml})$ in all studied groups of male and female albino rats. 


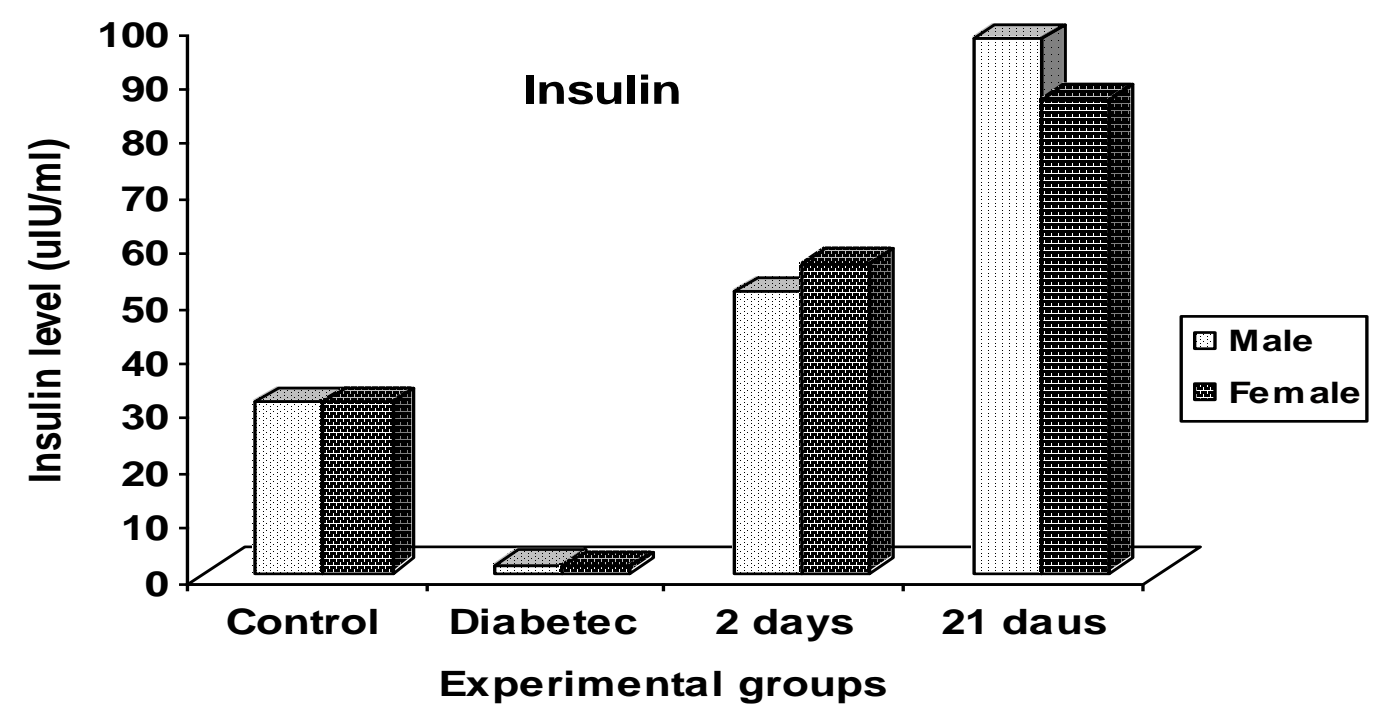

Fig. (2): Serum insulin level $(\mu \mathrm{IU} / \mathrm{ml})$ in all studied groups of male and female rats.

\section{Blood glucos}

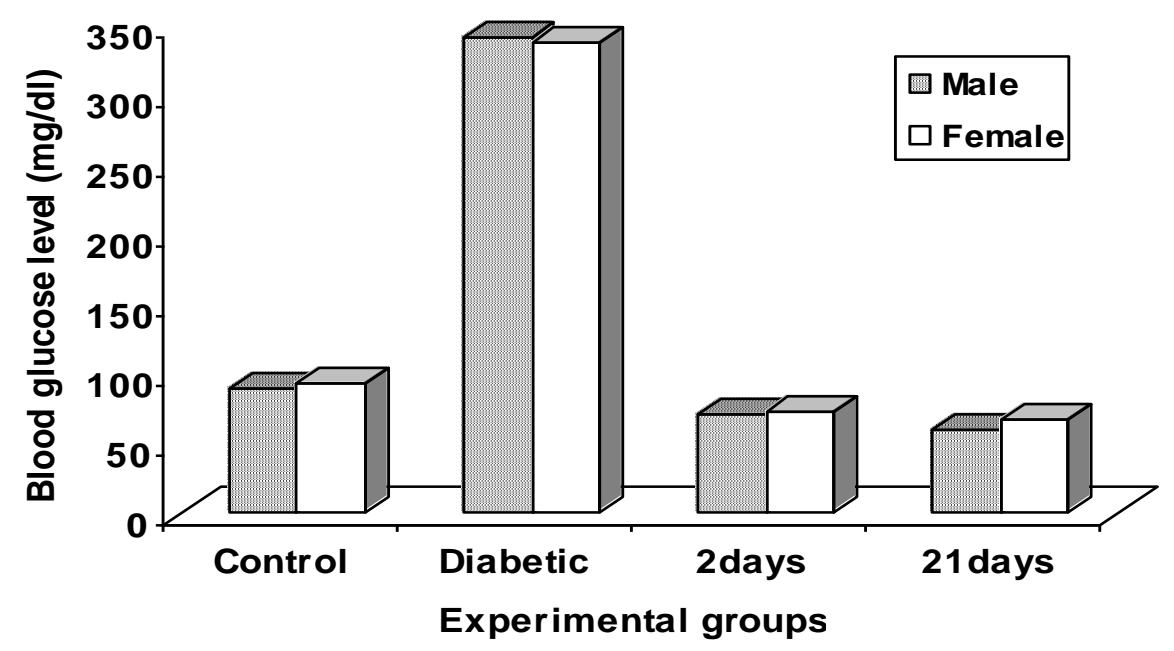

Fig. (3): Blood glucose level $(\mathrm{mg} / \mathrm{ml})$ in all studied groups of male and female rats. 


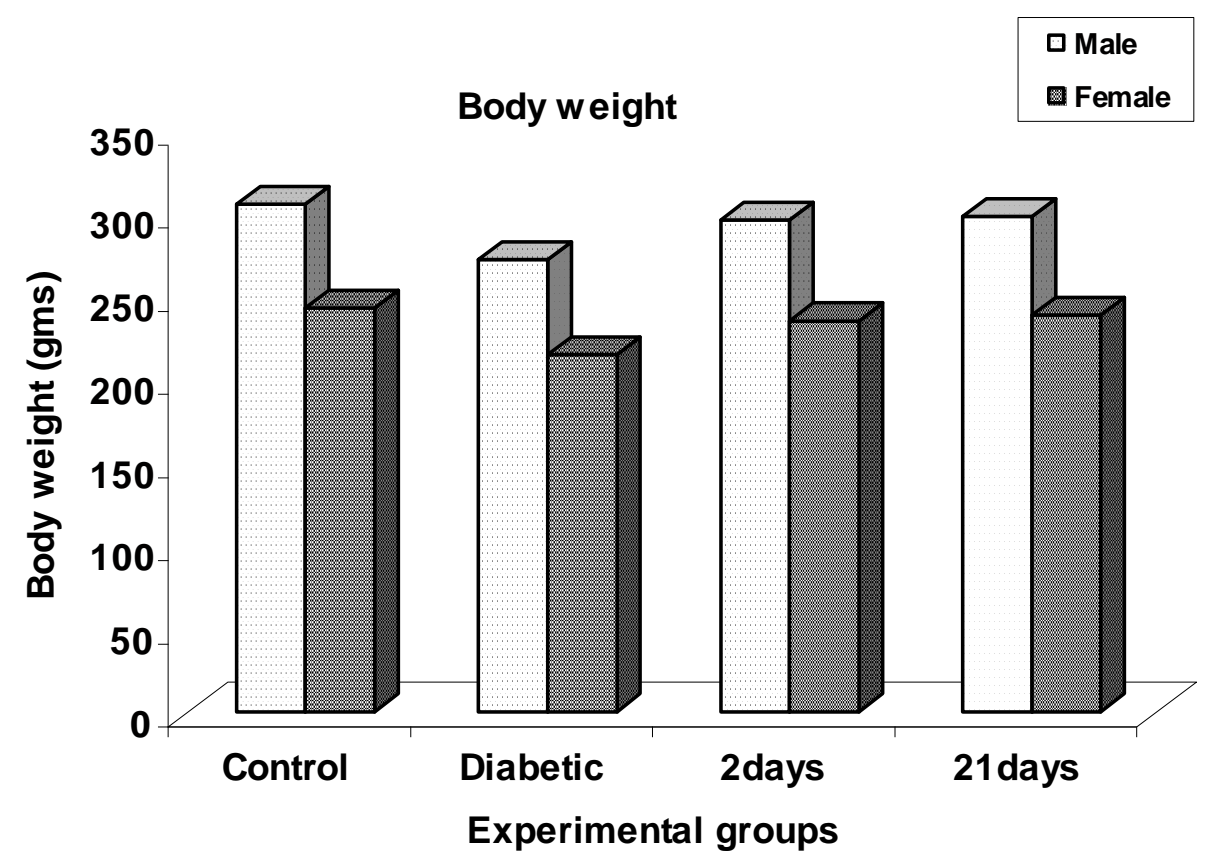

Fig. (4): Body weights (gms) in all studied groups of male and female rats.

\section{Discussion}

Leptin, a 167 amino acid protein transcribed from the obesity (ob) gene in the adipose tissue, was originally cloned in the mouse during research directed at identifying the molecular defect in obesity-prone strain (ob/ob mouse) (Zhang et al., 1994). The two most important parameters accounting for variations in leptin concentrations are sex and the amount of body fat (Considine et al., 1996).

The present study showed that female rats had significantly higher mean values of serum leptin levels than males in the control group. These data are consistent with results from prev ious studies in experimental animals (Yacout et al., 200) and humans (Kiess et al., 1998). The gender difference in serum leptin concentrations was also previously described in adults (Danne et al., 1997) and pediatric (Lahlou et al., 1997) healthy subjects, young patients with IDDM (Verotti et al., 1998).
Therefore, it could be concluded that gender seems to be important for the variation in the serum leptin concentration in adult normal rats. However, various factors such as the changes in blood glucose, insulin concentration, and pattern of feeding have emerged which appear to dominate the influence on leptin concentration other than gender. The most likely explanation for this difference is the greater adipose tissue mass in females than males whereas the muscle is greater in males than females. Besides this sex difference in body composition direct influence of sex steroids may be causative (Blum et al., 1997).

Numerous studies have reported the importance of sex steroids to account for the different leptin concentrations according to sex, and the existence of a negative correlation between testoster one concentrations and serum leptin concentrations in men (Elbers et al., 1997 
and Yacout et al., 2000), although others have not found thin correlation and suggested that, in men, sex hormones are not important independently modifiers of leptin concentrations (Haffner et al., 1997). However, Tuominen et al. (1997) found a negative correlation between leptin and testosterone in a study of male patients with type-1 diabetes mellitus, but not in controls. In the study of Martines et al. (2000), it was found that leptin concentrations in women were more than twice those in men despite the similarity of BMI values in both studied groups. They also failed to find a correlation between leptin concentrations and testosterone in the men with type-1 diabetes mellitus.

It was also found, in the present study, that there is no gender difference in serum insulin concentration in the control group. This finding demonstrates that insulin concentration could not be a factor explaining the gender difference in leptin concentration. In the present study, strong positive correlation was found between leptin concentration and body weight in the control male and female groups. Moreover a strong positive correlation was also found between leptin concen-tration and insulin hormone level in control male and female groups.

These findings clearly demonstrate that serum leptin concentration change in a direct proportion to the variation in body weight and insulin hormone serum level in the control group i.e. adult normal rats whether male or female, with high body weight or high serum insulin level had a higher serum leptin concentration than rats with low body weight and low serum insulin level.

These findings are consistent with previous studies recorded on the effect of body weight (Considine et al., 1995 and Niklas et al., 1997) and serum insulin level (Havel et al., 1996) on serum leptin concentration.

The present study revealed that streptozotocin induced diabetes resulted in a significant weight loss and a marked reduction in serum leptin concentration which was partially but significantly reversed after 2 days of insulin therapy and completely reversed to baseline (prediabetic) levels or may even overshoot above the base line after 21 days of insulin therapy. These findings are in agreement with the results of Sivitz et al. (1998) who observed that the reversal of the significantly reduced plasma leptin concentra-tions by insulin treatment of streptozotocin diabetic rats occurred before the return of the significantly reduced body weight or epididymal fat mass to baseline (prediabetic) levels. Hence, they suggested that insulin itself increased leptin concentrations indepe ndently of altered adipose mass.

Havel et al. (1998) found that leptin was markedly decreased in STZ diabetic rats as early as 24 hours to 48 hours after the induction of diabetes, but, before major decrease in body weight.They also, observed that plasma leptin was significantly decreased after 2 weeks and remained low through 12 weeks of STZ diabetes in rats with significantly lower body weight. They reported that the early changes of leptin were proportional to the changes of glycemia but not to changes of body weight. They attributed the weight loss during the first 24 hours to 48 hours after induction of diabetes mostly to loss of body water rather than body fat. In addition, Havel et al. (1998) showed that plasma leptin levels were increased by insulin treatment of STZ diabetic rats in proportion to the reduction of hypoglycemia.

In the present study, low leptin 
levels are present in diabetic rats before insulin treatment was begun is also in accordance with that of Kiess et al. (1998) who found that low leptin levels even after adjustment for body mass index (BMI), where present at clinical presentation of diabetes in a small cohort of children and adolescent with IDDM before insulin treatment was started.

There are several possible explanation for this finding: (1) low leptin levels in diabetic animals and/or in-patients with newly onset diabetes might be related directly to the absent or low insulin levels. In fact, data from animal experiments suggest that insulin directly induces leptin expression, pointing to insulin as an important regulator of leptin (Leroy et al., 1996).

In addition, STZ related mice have reduced leptin mRNA levels which are partially restored by insulin treatment (Mizuno et al., 1996). Many investi gators reported that the decrease in plasma leptin in STZ diabetic rats was observed to be consistent with the decrease in epididymal adipose tissue leptin mRNA levels (Sivitz et al., 1996 and Havel et al., 1998). Backer et al. (1995) reported a decrease in subcuta neous (inguinal) adipose leptin m RNA in STZ diabetic rats. This decrease in leptin mRNA was not rapidly reversible by insulin therapy and restoration to baseline (non diabetic) levels does not occur in rats prior to restoration of body weight (Baker et al., 1995 and Sivitz et al., 1996). Moreover, Sivitz et al. (1998) observed that the reduced body weight, epididymal fat mass, and epididymal adipose mRNA in STZdiabetic rats did recover at least, to baseline when insulin therapy was continued for 17 days.

Hence, they suggested that the increase in plasma leptin induced by insulin therapy does not depend on steady state message levels within adipose tissue depots but may depend on posttranscriptional cellular events regulating the translations, intra-cellular pooling, or peptide release or altered clearance of circulating leptin.

Insulin treatment has been previously demonstrated to increase ob mRNA in nondiabetic rats (Saladin et al., 1995) and normalize ob mRNA expression in some (MacDougard et al., 1995) but not all (Kolaczynski and Caro, 1996) studies of STZ diabetic rats. Although, it has been suggested that insulin could have a direct effect on leptin production and/or leptin express ion (Caro et al., 1996), studies performed in whole rats and primary rat adipocytes have not always demon strated a clear insulin effect on ob gene expression in STZ diabetic rats (Kolaczynski and Caro, 1996).

In humans, however, reports on the influence of insulin on leptin are conflicting. While in some studies in human leptin levels were not influenced by hyperinsulinemia (i.e.euglycemia clamp with steady state hyper-insulin emia from 80-120 $\mu \mathrm{IU} / \mathrm{ml}$ maintained for up to $5 \mathrm{~h}$ ) and meal-related increases in circula-ting insulin levels (Muscelli et al., 1996) although leptin levels showed a definite nocturnal rise in lean, obese, and diabetic subjects. Malmstrom et al. (1996) by using hyperinsulinemic clamps have also shown that insulin significantly stimulated serum leptin concentrations in man (patients with non IDDM).

In the study of Muscelli et al. (1996), the acute administration of insulin in physiological amounts and under euglycemic conditions did not change circulating leptin levels in lean, or obese subjects. Also, the data of Larrson et al. (1996) confirm that it is unlikely that insulin increases plasma leptin even at high circulating levels. 
Verroti et al. (1998) showed that leptin concentrations in diabetic patients treated with human insulin were similar to those in non-diabetic subjects. They attributed this finding to adequate metabolic control by intensive insulin treatment. It is well known that in diabetic patients with poor metabolic control, abnormalities of thyroid hormo nes, growth hormone binding proteins and other hormones are frequently detected (Adcock et al., 1994). In contrast, in diabetic patients with improved metab olic control, normalization of the above abnormalities is generally attained (Caro et al., 1996).

On the other hand, Tuominen et al. (1997) stated that fasting leptin levels were higher in IDDM subjects and remained unchanged during (acute) hyperinsulinemia (i.e. 4h.euglycemic hyperinsulinc clamp). These authors suggested that patients with IDDM are resistant to insulin action on leptin synthesis. The most direct proof, however, that insulin stimulates leptin expression and synthesis in humans stems from in vitro studies with differentiated human adipocytes (Wabitsch et al., 1996).

The present study demonstrated that the increase in plasma leptin in insulin treated STZ diabetic rats was evident as early as 2 days, while the study of Sivitz et al. (1996) showed that leptin mRNA remained well below the prediabetic levels after 2 days of insulin treatment and Backer et al. (1995) found that leptin mRNA in STZ diabetic rats treated with insulin up to 4 days still remained below the levels in non diabetic rats. Hence, in the present study, current 2 days plasma leptin results considered along with past studies of leptin message support the concept of a disacordance (disparity between circulating leptin and leptin message (leptin mRNA) in insulin treated diabetic rats).

However, Calpham et al. (1997) measured plasma leptin and subcuta neous adipose tissue leptin mRNA in non-diabetic lean and obese humans before and after a mixed meal and observed no change in either parameter despite a substantial increase in plasma insulin. However, there may be species differences in the rate of leptin response to insulin, or insulin mediated leptin release as, whereas the human studies imply that in vivo leptin responsiveness to insulin requires prolonged insulin administration, the results of the present study together with others (Sivitz et al., 1998) observed a rapid and substantial increase in leptin in STZ-diabetic rats. Certain factors could explain the discrepancy in insulin responsiveness between rodents and humans. It is known that insulin -induced glucose flux, measured as whole body glucose utilization, is higher in rodents than in humans even at equivalent glycemia (Kraegen et al., 1983). Hence, there may be a critical degree of insulininduced energy uptake beyond which leptin release is triggered.

Dissociation between changes of ob gene expression and changes of circulating leptin concentrations has been reported. For example, plasma leptin increases after increase dexamethazone administration in humans without a corresponding increase of adipose mRNA (Kolaczynski and Caro, 1996).

It should be noted that the circulating insulin concentrations produced by administering exogenous insulin to diabetic rats in these studies were substantially higher than in non diabetic control animals. These levels are, however, necessary to lower plasma glucose concentrations because STZ diabetes is associated with insulin 
resistance (Nishimura et al., 1989) in addition to insulin deficiency.

No strict correlation between insulin dose and plasma insulin was detected in diabetic patients because many different factors contribute to the modifications of plasma levels (route of administration, variability of absorption, kinetics of circulation) (Brunetti and Bolli, 1997).

Our study showed a positive correlation between serum leptin levels and serum insulin concentrations in both control and STZ diabetic rats. Several studies have revealed an association between insulin and leptin in both animals (Wabitsch et al., 1996) and humans (Saad et al., 1998), although others found no association between insulin and leptin in obese persons (Dagogo-Jack et al., 1996). In the study carried out by Martinez et al. (2000) in type-1 diabetic adults, no relation was found between leptin concentrations and daily insulin dose. A recent study found that leptin concentrations correlated significantly with insulin dose in prepubertal children, but not during puberty (Moll et al., 1998), although others, did not find this correlation in children with type 1 diabetes mellitus followed from the onset of their diabetes and after several weeks of insulin treatment (Ross et all., 1998). This lack of a significant correlation between insulin dose and leptin concentrations was also noted by Tuominen et al. (1997) in adult patients with type- 1 diabetes mellitus.

(2) Alternatively, very high blood glucose concentrations in cases of diabetes mellitus could also suppress leptin levels. However, data regarding a putative regulation of leptin expression by glucose are conflicting. In mice and humans, ob mRNA was inhibited by food restriction associated with glucopenia and was stimulated by injections of glucose in some (Ostlund et al., 1996) but not in other studies (Funahashi et al., 1995).

In the present study, a negative correlation between serum glucose and leptin concentrations was found. Kiess et al. (1998) found no correlation between serum glucose and leptin concentations in IDDM patients receiving insulin. Verrotti et al. (1998) found no significant correlation between blood glucose level and leptin in either control or diabetics treated with insulin (obese and non obese).

Many physiological studies suggested that variations in blood glucose are not an active signal for leptin secretion (Lahlou et al., 1997). A number of published studies have found that short term insulin adminis-tration does not increase plasma concentrations in human subjects (Dagogo-Jack et al., 1996).

In contrast, some other studies have demonstrated significant increases of circulating leptin concentrations after 4$6 \mathrm{~h}$. of high dose insulin and glucose infusion in non diabetic (Utriainen et al., 1996) and diabetic human subjects (Havel et al., 1996).

Furthermore, infusions of glucose alone, resulting in hyperglycemia, and concomitant endogenous hyperinsul inemia, increases plasma leptin within $4 \mathrm{~h}$ in humans (Sonnenberg et al., 1996). There is evidence that the induction of marked hyperinsulinemia is not required to increase plasma leptin concentra tions. For example, low dose glucose infusion sufficient to prevent the decline of plasma insulin and glucose during fasting also prevents the decline of plasma leptin (Boden et al., 1996). In addition, lowering plasma glucose concentrations to euglycemia in hyper glycemic insulin- dependent diabetic human subjects by infusing insulin at 
rates that produced physiological insulinemia increases circulating leptin (Havel et al., 1996).

Therefore, an effect of insulin to increase adipose tissue glucose uptake and metabolism, rather than hyperins ulinemia per se may be involved in stimulating leptin secretion (Havel et al., 1998). Consistent with this hypothesis, Mueller et al. (1998) have found that stimulation of leptin secretion by insulin from in vitro cultured rat adipocytes is closely related to the effects of insulin to increase adipocyte glucose uptake. In the same study, blocking glucose uptake with 2-deoxy-Dglucose, phloretin, or cytochalasin-B or inhibiting glucose meta-bolism with iodoacetate or sodium fluoride produced inhibitions of leptin secretion that were related to decreased glucose utilization, despite the presence of high insulin concentrations. Thus, hypoleptinemia in un-regulated insulindeficient diabetes may be a consequence of decreased glucose uptake and metabolism in adipose tissue, whereas the restoration of circulating leptin levels by insulin treatment in diabetic animals may be secondary to increased adipocyte glucose uptake and utilization.

(3) Diabetic animals before the initiation of insulin treatment had low body weight values that were also significantly lower than body weight values in treated diabetic animals. Thus a reduced body fat mass due to increased lipolysis following insulin deficiency might have resulted in reduced absolute leptin levels in untreated diabetic animals (Kiess et al., 1998). Moreover, assuming that the reduced body weight of diabetic animals was, in part, also due to dehydration (Havel et al., 1998), the calculation of leptin would over-rather than underestimate leptin values with respect to fat mass. Furthermore, the present study, in agreement with that of Kiess et al. (1998), demonstrated a positive correlation between serum leptin levels and body weight or (BMI), and insulin. Sivitz et al. (1998) suggested that the absolute level of adipose cell energy storage may not be as critical for fat cell leptin release as the level of circulating insulin or the rate of insulin-induced energy entry or energy flux. These findings suggest, therefore, that insulin may indeed be an important regulator of leptin levels.

(4) Potential effects of other insulin or glucose responsive factors in modulating the leptin response to insulin in this in vivo study can not be excluded. In particular serum cortisol, which is known to stimulate adipose leptin production, may have played a role (De-Vos et al., 1995). However, this would be more likely to occur in hypoglycemia.

In conclusion, the present study revealed that: $1-G e n d e r$ is one of the physiological factors which affect circulating leptin level. 2-Since, plasma leptin concentrations are volatile in insulin treated diabetic rats, being markedly reduced under conditions of insulin deficiency and rapidly reversed with insulin treatment, insulin is one of the most important factors in the regulation of circulating leptin level. 3As leptin concentration was found to correlate directly with insulin level and body weight but inversely with blood glucose level, factors other than insulin are involved in the physiological regulation of circulating leptin concent ration such as body weight and blood glucose level.

\section{References}

1. Adcock, C.J., Perry, L.A., Lindsell, A.M., Taylor, A.M., Holly, J.M. and Jones, J. (1994): 
Menestrual irregularities are, more common in adolescents with type I1 diabetes: association with poor glycemic control and weight gain. Diabetic Medicine, 11 : 465-470.

2. Ahren, B.; Mansson, S.; Ronald, L.G. and Havel, P.J. (1997): Regulation of plasma leptin in mice: Influence of age, high fat diet and fasting. Am. J. Physiol., 273:R113R120.

3. Auwerx, J. and Staels, B. (1998): Leptin. The lancet 351 (March 7): 737-742.

4. Backer, D.J., Ongemba, V., Brichard, V., Henquin, J.C., and Brichard, S.M. (1995): Diet and diabetes induced changes of ob gene expression in rat adipose tissue FEBS Lett. , 371: 324-328.

5. Blum, W.E., Englaro, P., Hanitsch, S., Juul, A.\& Hertel, T.N, Skakkebaek, N.B. , Attanasio, A. and Rascher, W. (1997): Serum leptin levels in healthy children and adolescents: depe ndence in body mass index, gender and develop-mental stage. J. Clin. End. \& Metab., 82: 2904-2910.

6. Boden, G., Chen, X., Mozzoli, M., and Ryan, I. (1996): Effect of fasting on serum leptin in normal human subjects. J. Clin. Endocrinol. Metab., 81: 3419-3423.

7. Brunetti, B., and Bolli, G.B. (1997): Pharmacokinetics and phar macodynamics of insulin: relevance to the therapy of dibetes mellitus . Diabetes Nutrition \& Metabolism, 10: 24-34

8. Calpham, J.C., Smith, S.A. and Moore, G.B. (1997): Plaasma leptin concentrations and ob gene expression in subcutan-eous adipose tissue are not regulted acutely by physio-logical hyperinsulinemia in lean and obese human. Int. J. Obs. Rel. Metab. Disord., 21: 179- 183.
9. Caro, J.R., Sinha, M.K., Kolaczynski, J.W., Zhang, P.L. and Considine, R.V. (1996): Leptin the tale of an obesity gene. Diabetes,45: 1455-1462.

10. Considine, R.V., Sinha, M.K., Heiman, M.L., Heiman, M.L., Kriauciunas, A., Stephans, T.W., Nyce, M.R., Ohannesian, J.P., Marco, C.C., Mckee, L.J., Bauer, T.I. and Caro, J.F. (1996): Serum immunoreactive leptin concentrations in normal weight and obese humans. N. Engl. J. Med., 334: 292-295.

11. Dagogo-Jack S., Fanelli, C., Paramore, D., Brothers, J. and Landt, M. (1996): Plasma leptin and insulin relationship in obese and non-obese humans. Diabetes , 45: 695698.

12. Danne, T., Gruters, A., Wladimirova, A., Weber, B., Horn R. and Mayr, B.(1997): Gender specific differences of serum leptin in obese and normal weight adolescents: Studies in type -1 diabetes and Turner syndrome. Horm. Research, 48: 103-107.

13. De-Vos, P., Saladin, R., Auwex, J. and Staels, B. (1995): Induction of ob gene expression by corticosteroids is accompanied by body weight loss and reduced food intake. J. Biol. Chem., 27: 15958-15961.

14. Dubuc, G.R., Stephen, D.P., Stern, J.S., and Havel, P.J. (1998): Changes of serum leptin and endocrine and metabolic parameters after 7 days of energy restriction in men and women. Metabolism, 47 (4): 429-434.

15. Elbers, J., Asschemal, H., Seidel, J., Frplich, M. and Gooren L. (1997): Reversal of sex differences in serum lepten levels upon cross sex hormone administration in transsexual. J. Clin. Endoc. Metab., 82:3267-3270. 
16. Erickson J., Clegg, K. and Palmiter, R. (1996): Sensitivity to leptin and susceptibility to seizures of mice lacking neuropeptide Y. Nature, 381: 415-418.

17. Funahashi, S., Vimelli, S. and Kuhn, C.M. (1998): Muscarinic stimulation and antagonism and glucoregulation in non diabetic and obese hypoglycemic mice. Diabetes, 38:1433-1438.

18. Hamilton, B.S.; Laglia, D.; Kwan, A.Y. and Deited, M. (1995): Increased obese mRNA expression in omental fat cells from massively obese humans. Nature Med., 1:953956.

19. Havel, P. J., Kasim - Karakas S., Mueller W., Johnson P.R., Gingerich R. L., and. Stern J.S. (1996): Relation-ship of plasma leptin to plasma insulin and adiposity in normal weight and overweight women:: Effects of dietary fat content and sustained weight loss. J. Clin. Endocrinol. Metab., 81: 4406-4413.

20. Havel, P.J., Hare, J.Y., Liu, T., Stanhope Stern J.S., Keen, C.L., and Ahren,B. (1998): Marked and rapid decreases of circulating leptin in streptozotocin diabetic rats: reversal by insulin Am. J. physiol., 274 : R1482-R14891

21. Haffner, S., Miettinen, H. Karhapa, P., Mykanen, L. and Lakso, M.(1997): Leptin concentr ations, sex hormones, and cortisol in nondiabetic men. J. Clin. Endoc., 82: 1807-1809

22. Harry， P.K., Santarosa， R.P., Butyan R., Shabsigh, R., Olson, C.A., and Kaplan ,S.A. (1993): Early molecular changes associated with STZ-induced diabetic bladder hypertrophy in rat. Urological Research., 21: 375-381.
23. Huszar, D., Lynch, C.A. and Fairchild-Huntress, V. (1997): Targeted disruption of the melanoc ortin-4 receptor results in obesity in mice. Cell , 88: 131-141.

24. Kiess, W.; Anil, M.; Blum, W.F.; Englaro, P. et al. (1998): Serum leptin levels in children and aldossent with insulin dependent diabetes mellitus in relation to metabolic control and body mass index. Eur. J. Endoc., 138:501-509.

25. Kolaczynski, J.W. and Caro, J.F. (1996): Molecular mechanism of insulin resistance in human obesity. Diabetes, 3: 36-43,

26. Kragen, E.W.; James, D.E. and Benett, S.B. (1983): In vivo insulin sensitivity in the rats determined by euglycemic clamp. Am. J. Physiol., 245: E1-E37.

27. Lahlou, N., Landais, B., De Boissieu, D., and Bougneres, B.F. (1997): Circulating leptin in normal children and during the dynamic phase of juvenillle obesity. Relation to body fatness, energy metabolism, caloric intake and sexual diamorphism, Diabetes,46: 989-993.

28. Larsson, H., Elmstahl, S. and Ahren, B. (1996): Plasma leptin levels correlate to islet function independently of body fat in postmenopausal women. Diabetes., 45 : 1581-1584.

29. Leroy, P., Dessolin, S., Villageois, P., Moon, B.C., Friedman, J.M., Ailhaud, G. and Dani,C.(1996): Expression of ob gene in adipose cells: regulation by insulin . J. Biol. Chem., 271:2365-2368

30. Lutz, A.J. and Pardridge, W.M. (1993): Insulin therapy normalizes GLUT1 glucose transporter mRNA but not immunoreactive transporter protein in streptozocin- diabetic rats. Metabolism, 42: 939-944. 
31. MacDougard, O.A.; Hwang, C.S.; Fan, H. and Lane, M.D. (1995): Regulated expression of the obese gene product (Leptin) in white adipose tissue and 3T3-LI adipocytes. Proc. Natl. Acad. Sci. U.S.A., 92:9043-9037.

32. Malmstrom, R., Taskinen, M.R., karonen, S.L. and Ykijarvinen, $H$. (1996): Insulin increases plasma leptin concen-trations in normal subjects and patients with NIDDM. Diabetologia., 39:993-996.

33. Martinez, G.R., Soriguer, F.J., Gonzalez-RAmero ,S., Tnahons,E. , Moreno F, Ruiz de Adana, S. , Garriga, M.J., Esteva, I. and Garcia-Almedia, M. ( 2000): Serum leptin and habitual fatty acid dietary intake in patients with type 1 diabetes mellitus Eur. J. of Endocrin., 142: 263-268.

34. Mizuno, T. M., Bergen, H., Funabashi, T., Kleopoulos, S. P, Zhong, Y. G., Bauman, W. A., and Mobbs, C. V. (1996): Obese gene expression: reduction by fasting and stimulation by insulin and glucose in lean mice, and persistent elevation in acquire (diet induced) and genetic (yellow agouti) obesity. Proc. Natl. Acad. Sci. USA., 93: 3434-3438

35. Moll, G., Britt, R., Welch, D. and West, S. (1998): Leptin levels reflect total daily insulin use in pubertal and prepubertal IDDM patients. Diabetes, 47: A404-7.

36. Mueller, W.M., Gregoire, H., Stanhope, K.L., Mobbs C.V., Mizuno, T.M., Warden, C.H., Stern, J.S. and Havel, P.J. (1998): Evidence that glucose metabolism regulates leptin secretion from cultured adipocytes. Endocrinology, 139: 551-581.

37. Muscelli, E. , Camastra, S., Masoni, A., Baldi, S., Sironi,
A.M., and Natali, A.(1996): Acute insulin administration does not affect plasma leptin levels in lean and obese subjects. Eur. J. of clinical Investigaytion, 26: 940-943

38. McGregor. G.P., Desaga, J.F., Ehlenz K., Fischer A., Heese F. and Hegele A. (1996): Radioimmunology measurement of leptin in plasma of obese and diabetic human subjects. Endocrinology; 137:1501-1304.

39. Nicklas, BJ., Katzel, L.I. and Ryan, A.S. (1997): Gender differences in the response of plasma leptin concentrations to weight loss in obese older individuals . Obes. Res., 5: 62-68.

40. Nishimura, H.; Kuzuya, H.; Okamata, M., Yamada, A. et al. (1989): Post receptor defect in insulin action in STZ induced diabetic rats. Am. J. Physiol., 256:E624-E630.

41. Ostlund, R.E., Yang, J.W., Klein, S., and Gingerich, R. (1996): Relation between plasma leptin concentration and body fat, gender, diet, and metabolic covariates J. Clin. Endocrinol. Metal., 81: 3909-3913.

42. Ross, H.; Mick, G.; Parton, E.; Totka, J.; Butterfield, J. and Mccormick, K. (1998): Leptin levels in newly-diagnosed type-1 diabetic children before and following insulin therapy. Diabetes, 47:A408.

43. Saad, M.F., Riad-Gabriel, M.G. and Khan, A. (1998): Diurnal and ultradian rhythmicity of plasma leptin: Effects of gender and adiposity. J Clin Endocrinol Metab.,83: 453-459.

44. Saladin, R., Staels, B., Auwerx, J., and Briggs, M. (1996): Regulation of ob gene expression in rodents and humans. Horm. Metab. Res., 28: 638-641. 
45. Sivitz, W.I., Bailey, H.L., and Donohoue, P. (1996): Rat adipose ob mRN levels in states of altered circulating glucose and insulin Biochem. Biophys. Res. Commun., 220: 520-525.

46. Sivitz, W.I., Walsh, S., Morgan, D., Donohoue, B., Haynes, W. and Leibel, L. (1998): Plasma leptin in diabetic and insulin treated diabetic and normal rats. Metabolism, 47: 584591.

47. Sonnenberg, G.E., Krakower, G.R., Hoffmann, R.G., Mass, D.L., Hennes, M.M.I. and Kissebah, A.H. (1996): plasma leptin concentration : effects of extended fasting and stepwise increases in glucose infusion (abstract). Obesity Res., 4: 135.

48. Spina, M., Merlo-Pich,E. and Chan, R.K. (1996): Appetitesuppressing effects of urocortin, a CRF-related neuropeptide. Science, 273: 1561-1564.

49. Tuominen, J.A., Ebeling, P. and Stenman, U.H. (1997): Leptin synthesis is resistant to acute efffect of insulin in IDDM patients. J. Clin Endoc. Metab., 82; 381-382.

50. Utriainen, T., Malmstrom R., Nakimattila S., and Yki-Jarvinen H. (1996): Supra-physiological hyperinsulinemia increases plasma leptin concentrations after $4 \mathrm{~h}$ in normal subjects. Diabetes, 45: 13641366.
51. Verrotti , A. , Basciani, F., Morgese, G. and Chiarelli, F. (1998): Leptin levels in non obese and obese children and young adults with type 1 diabetes mellitus. Eur. J. Endoc., 139: 49-53.

52. Wabitsch, M., Jensen, P. B., Blum, W. F., Christoffersen, C.T.,. Englaro, P., Heinze E., Rascher, W., Teller, W., Tornqvis, H. T. and Hauner, H. (1996): Insulin and cortisol promote leptin production in cultured human fat cell. Diabetes, 45: 1435-1438.

53. Yacout, M.M., El-Ghannam, AbdAllah, S. and Ibrahim K. (2000): The role of gender and effect ogf gonadectomy and sex steroids (estradiol and testosterone)on the serum leptin level in rats. Z.U.M.J. Special issue, Nov: 403-422.

54. Yamane T. (1970): Statistics an Introductory analysis, 2 nd Edition. A Harper international edition over expressing leptin. J.Clin . Invest., 105: 749-755.

55. Zhang, Y., Proenca, R., Maffei, M., Barone, M., Leopold, L. and Friedman, J. (1994): Positional cloning of the mouse obese gene and its human homo-logue. Nature, 372: 425-432. 


\section{تأثير السكر المحدث تجريبيا علي مستوى الليبتين في مصل اللم ودور العلاج التعويضي هئي بالأنسولين نبيل عباس أحمد سليمان}

قسم علم الحيوان - كلية العلوم - جامعة الزقان سليمان

لقد اكتشف حديثا ان الأنسجة الدهنية تفرز مـادة تسمى اللييتين وقد وجد أنها تقلل الطيل

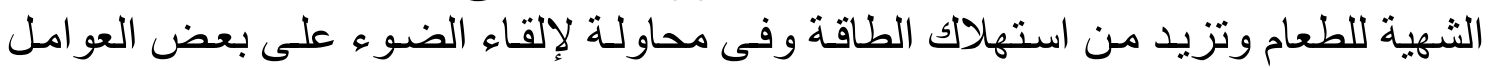

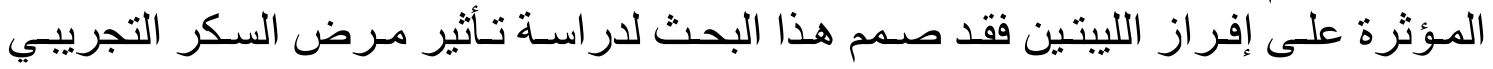

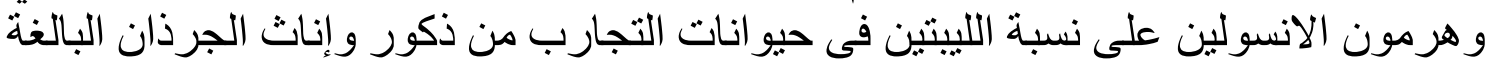

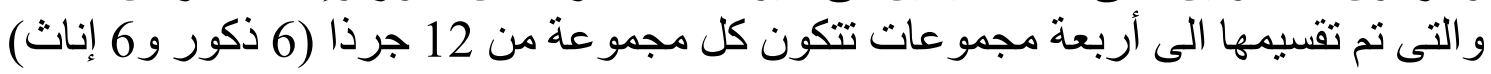
كما يلي: المجموعة الأولي : الضابطة

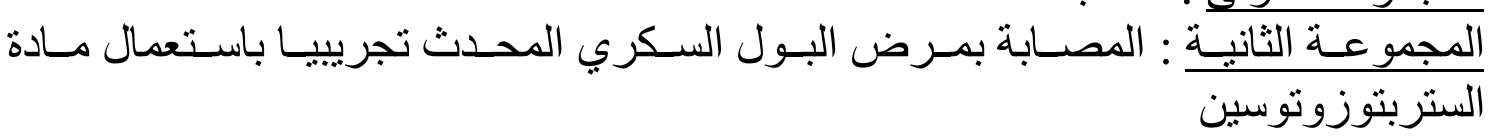

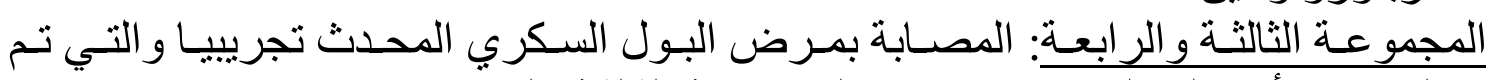

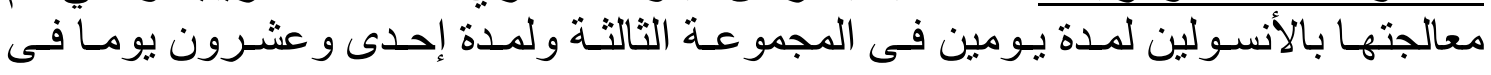

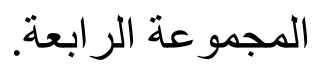
هذا وقد أظهرت النتائج وجود ارتفاع ذو دلالة إحصائية فى مستوى تركيز مادة اللييتين

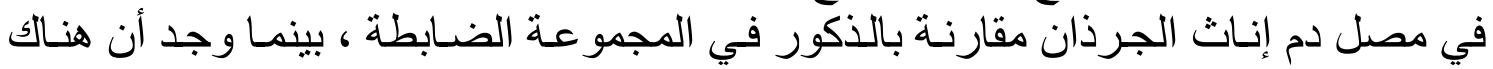

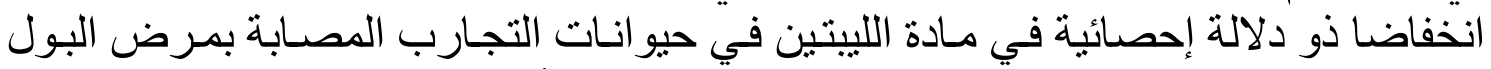

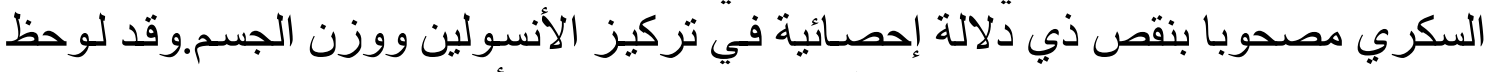

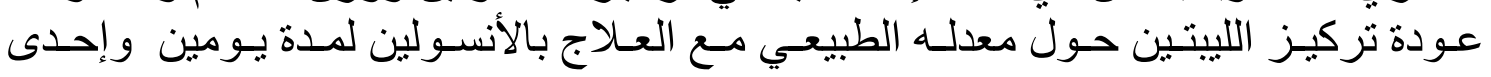
و عشرون يودما.

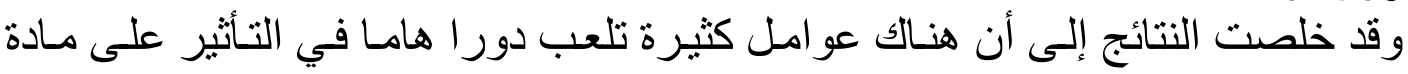

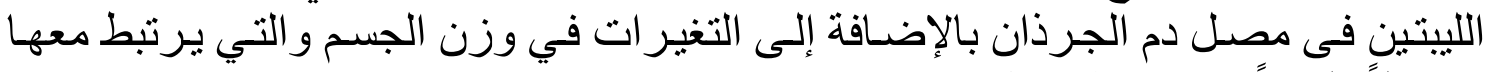

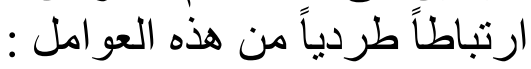
1

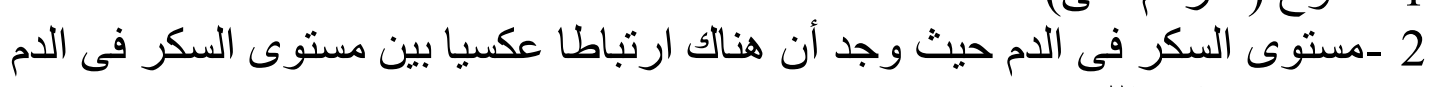
وتركيز مادة الليتينين 3 -تركيز الأنسولين في الدم حيث وجد أن هنالك ارتباطسا طردياً بين مستوى الأنسولين و الليبتين 